Maurer School of Law: Indiana University

Digital Repository @ Maurer Law

\title{
A Different Departure: A Reply to Shany's "Redrawing Maps, Manipulating Demographics: On Exchange of Populated Territories and Self-Determination"
}

Timothy W. Waters

Indiana University Maurer School of Law, tiwaters@indiana.edu

Follow this and additional works at: https://www.repository.law.indiana.edu/facpub

Part of the Civil Rights and Discrimination Commons, and the International Law Commons

\section{Recommended Citation}

Waters, Timothy W., "A Different Departure: A Reply to Shany's "Redrawing Maps, Manipulating Demographics: On Exchange of Populated Territories and Self-Determination"' (2008). Articles by Maurer Faculty. 21.

https://www.repository.law.indiana.edu/facpub/21

This Article is brought to you for free and open access by the Faculty Scholarship at Digital Repository @ Maurer Law. It has been accepted for inclusion in Articles by Maurer Faculty by an authorized administrator of Digital Repository @ Maurer Law. For more information, please contact rvaughan@indiana.edu. 


\section{Law \& Ethics of Human Rights}

Volume 2, Issue 1

2008

Article 11

DEMOGRAPHY AND HUMAN RIGHTS

\section{A Different Departure: A Reply to Shany's "Redrawing Maps, Manipulating Demographics: On Exchange of Populated Territories and Self-Determination"} Timothy William Waters* 


\title{
A Different Departure: A Reply to Shany's "Redrawing Maps, Manipulating Demographics: On Exchange of Populated Territories and Self-Determination"*
}

\author{
Timothy William Waters
}

\begin{abstract}
Anyone reading Yuval Shany's response to my article, "The Blessing of Departure-Exchange of Populated Territories The Lieberman Plan as an Abstract Exercise in Demographic Transformation," would hardly characterize it as "agreement." In part this is because Shany builds his case by assuming I am saying something about self-determination that misses-at least misplaces-my real point. This is unfortunate, both as it masks the fact that Shany and I actually agree transfers can be legal, and it distracts attention from the points of real, substantive disagreement. The misreading is not an accident, rather the product of a patterned view. The points of disagreement, center on: whether transfer is a harm per se; whether the presence of a minority affects the state's power to transfer; whether there is a positive right not to be denationalized; and whether there is a hierarchy of rights.
\end{abstract}

${ }^{*}$ Sincere thanks to Prof. Yuval Shany, whose thoughtful response prompted this reply, and Rachel Guglielmo. Comments to tiwaters@indiana.edu. 
Waters: A Different Departure

\section{A DIFFERENT DEPARTURE: A REPLY TO SHANY'S “REDRAWING MAPS, MANIPULATING DEMOGRAPHICS: ON EXCHANGE OF POPULATED TERRITORIES AND SELF-DETERMINATION"}

\section{Timothy William Waters*}

\section{A Different READING}

Halfway into his excellent and forceful response, it turns out Yuval Shany agrees with me: "This does not mean, however, that the State of Israel cannot cede land or even, in theory, denationalize part of its citizenry.... [T] he legality of such moves would need to be grounded in the state's general sovereign powers." So states can transfer territory and denationalize citizens, consistent with human rights: this is, almost exactly, my argument too.

Still, anyone reading Shany's response would hardly characterize it as "agreement." In part this is because Shany builds his case by assuming I am saying something about self-determination that misses - at least misplaces - my real point. This is unfortunate, both as it masks the fact that Shany and I actually agree transfers can be legal, and it distracts attention from the points of real, substantive disagreement. I will say something later about this misreading - not an accident, rather the product of a patterned view_-but I think it better

*Associate Professor, Indiana University School of Law (Bloomington).

Sincere thanks to Prof. Yuval Shany, whose thoughtful response prompted this reply, and Rachel Guglielmo. Comments to tiwaters@indiana.edu.

${ }^{1}$ Yuval Shany, Redrawing Maps, Manipulating Demographics: On Exchange of Populated Territories and Self-Determination, 2 L. \& Eтнісs Hum. RTs 286, 301 (2008) (and 303, using similar language in conclusion). 
to address the points of disagreement, which center on these things:

- whether transfer is a harm per se;

- whether the presence of a minority affects the state's power to transfer;

- whether there is a positive right not to be denationalized; and

- whether there is a hierarchy of rights.

These are questions about how to characterize doctrine, but they also reveal different normative commitments concerning citizenship and states, and-considered together with our real disagreement about self-determination - say something troubling about what, for convenience, we may call "cosmopolitanism."

\section{Doctrinal Differences: Four ObJections, One Assumption}

Our agreement is limited. Even though he acknowledges that transfers are possible (a view already beyond what some scholars admit), Shany thinks this transfer - the Lieberman Plan - is clearly illegal. Some of his reasons are anticipated, and answered, in my article, ${ }^{2}$ so here I consider only certain objections that indicate a deeper divergence: These include the real risk doctrine, the right of option, and the claim that I construct an impermissible hierarchy with sovereign control of territory trumping rights. These objections fail, but more importantly, the ways in which they fail share a common defect: an assumption that a state polity has an essential, even moral, integrity.

\footnotetext{
${ }^{2}$ Shany lists rights that transfer violates, but I show that, because these rights gain content through membership in a polity (which is grounded in affinities arising from residence in a particular place), a transfer of territory also transfers to the new sovereign responsibility for those rights. Likewise, he claims the Plan's discriminatory raison d'être disqualifies it, but I show how states in fact have broad latitude to circumvent this demonstrably porous prohibition, as the Plan does by targeting territory in the name of preserving (Jewish) democracy.
} 
Waters: A Different Departure

A. Real Risk, But to What?

Shany and I agree that states normally have the right to transfer territory and denationalize citizens. A human rights claim would trump that - Shany and I agree on this too-but only if the state's action would constitute a violation. So, would it?

Saying yes, Shany invokes the "real risk" doctrine: Transfer is invalid because it creates a real risk that transferees' human rights would be violated. Citizens of wealthy, rights-respecting Israel would join impoverished, violent Palestine: Health care would decline, repression increase. ${ }^{3}$ Shany's objection relies on current levels of rights in the West Bank, but nothing in the Plan - or the idea of transfer-requires us to assume that any individual will necessarily be subjected to treatment that in the absence of transfer would constitute a violation. Even if the doctrine barred placing individuals in worse situations, that would still allow a broad category of transfers: It would be interesting to consider Shany's response if Lieberman proposed transferring Umm el Fahm to, say, Norway. Real risk doctrine might prohibit a particular transfer, but it is wholly inapposite to analyzing changes in sovereignty as a general category; it is not a bar to this kind of thing.

But this presents a problem for Shany, since he also says that the Arabs' loss of Israeli citizenship and community with other Israelis violates their human rights. Indeed, it seems clear that Shany's real objection is not to the harmful loss of health services or education, but to the transfer itself, which severs common bonds of citizenship and identity. That kind of harm springs not from any discrete violation by or shortcoming of the receiving sovereign-which is what real risk doctrine normally contemplates ${ }^{4}$ - but as a function of transfer

\footnotetext{
${ }^{3}$ Not to mention that, of course, transferees would also be subjected to an illegal occupation.

${ }^{4}$ Real risk doctrine has been applied almost exclusively to cases of extradition or deportation in which individuals faced specific harm, such as torture, or suffered a specific medical condition requiring treatment. It has never been applied to a generalized denationalization resulting from a transfer of sovereignty.
} 
itself. If he is right, transfer causes an absolute harm by the very act of changing borders.

This argument proves too much: If it were right, there could never be a legitimate transfer, since all transfers break existing political communities. But transfer is possible- we agree on that - and in the postwar era many states have formed from other, existing states without anyone suggesting that their varying ability to realize progressive human rights - or their sundering of existing political communities ${ }^{5}$ constituted a violation of human rights. ${ }^{6}$

Some transfers may harm individuals, and sometimes that harm may violate human rights. But the only things all transfers do are move borders and change citizenship; the real risk of transfer is to the integrity of an existing political community.

\section{B. Constructing Minority Status:}

There is something curious in the attempt to elevate the bare fact of common citizenship - itself a function of where borders happen to be - into an absolute bar against changing those borders. This is especially clear, and troubling, if we consider the weight placed

\footnotetext{
${ }^{5}$ Citizens have the right to travel about, and live within, their state. But Shany's claim that transfer violates this right is at odds with state practice: Slovenes can no longer move to Belgrade, or Belarusians to Samarkand - and nobody frames this as a "violation." When the territory of a state changes, the scope of mobility changes too. It cannot be - as a logical matter or a legal one - that the right to move within a state determines the shape of that state: the right is coextensive with the state's territory whatever it happens to be.

6 Some examples: partition of British India; withdrawal of Singapore from Malaysia; independence of Algeria; independence of East Pakistan; dissolutions of the Soviet Union and Yugoslavia; division of Czechoslovakia; separation of Eritrea and Ethiopia. For Shany, dissolution is inapposite, since "the creation of new states... do[es] not involve denationalization." (Shany, supra note 1, at 307). This is doctrinal formalism: While it is notionally possible for a state's authority to dissolve, following a plague or natural disaster, say, in the actual cases we call dissolution, there was no precipitating collapse, rather the act of secession itself signaled dissolution.
} 
on protecting the Arabs' minority status. Shany argues that transfer would break this minority into two groups, violating the rights both of those cut off from Israel and those left behind in it. But the Israeli Arab minority is not some autochthonous, primordial organism; it is, in the first instance, a construct of the Israeli frontier. Arabs on one side are members of the minority, those on the other subjects of the occupation - and claimants to Palestinian statehood. With different borders, Israel's Arab minority might be its majority $;^{7}$ with different borders, any given member of that minority might be, well, just another Arab in the West Bank. The difference is the border. ${ }^{8}$

Where a group exists, definitionally, because of a border, I do not think there is doctrinal or even logical support for the proposition that the group's rights are violated by that border's revision. ${ }^{9}$ Minority status is a residual and remedial category; no one affirmatively wishes to be a minority for its own sake. So it is curious to construct that status as something absolute that shapes the state rather than being shaped by the state, indeed made necessary by it. Still, that he maintains otherwise, positing an essential, irreducible identity for Arabs qua minority - and it is worth remembering, a minority in relation to

${ }^{7}$ Transfer does destroy Arabs' minority status-by making them members of the neighboring state's majority. Would we reject a single state in Cisjordan on the grounds that it would destroy Israeli Arabs' minority identity?

8 This is not to deny difference and complexity within Cisjordanian ArabPalestinian society, nor the common frames of reference Israeli Arabs uniquely share after 60 years. See, e.g., Ali Haider, Arabs Here to Stay: 'Population Exchange Notion Leaves Arab-Israelis No Choice but to Seek World's Help, YneTnews.com, Aug. 24, 2007, available at http://www.ynetnews.com/articles/0,7340,L-3441007,00.html (last visited Dec. 6, 2007) ("the Arab population in Israel is one national group whose social and cultural formulation since 1948 enjoys collective aspects"). But neither should we deny other frames of reference, nor the decisive role of borders in defining and maintaining categories of difference.

${ }^{9}$ I know of no border revision or new state rejected on the grounds that it changed the composition of a minority. A similar proposition was rejected by the Badinter Commission, which did not view divisions introduced among Yugoslavia's ethnicities as an obstacle to formation of new states, thoughit did require those new states to respect minority rights. Conference on Yugoslavia, Arbitration Commission, Opinion 2, 31 I.L.M. 1497 (1992). 
what? - suggests how central the defense of a common polity is for Shany. And he proposes other means to defend it.

\section{A Right of Option?}

Arguments about the irrelevance of rights would fail if there were a positive right to retain one's citizenship. And Shany says there is: a "right of option" that allows affected populations to choose between citizenship in the new state or the old.

Here again, state practice suggests there is no such right: Among all the examples noted before of states that were newly constituted or changed their frontiers, none accorded an option - and no one described those as human rights violations. Indeed, examining Shany's argument, the evidence is thin - two agreements allowing ex gratia retention of citizenship ${ }^{10}$ - and the principal engine for his claim is bare preference: This is a good thing that he feels ought to be a law. And while this might be a good and generous thing - after all, who does not want options?we must acknowledge a corollary: Granting an option to the Arabs in effect denies the "option of departure" for the Jews - departure, that is, not in a physical sense, but from the project of a community. A right of option is a veto on changing the polity; it constructs citizenship as an almost indissoluble — indeed, inescapable — category.

\section{Whose Hierarchy?}

So who gets an option: the state or its people? Supposedly, I create a hierarchy with "human rights... subordinated to the political configuration of the state, which is, in turn, governed by the right to selfdetermination." "11 But this in no way follows from my argument, which is about the scope of rights. A transfer that violated human rights would be void - but no right is implicated. Certain rights are instantiated through

${ }_{10}$ Neither agreement-the 2000 Treaty of Jeddah nor the ICJ ruling in Bakassi-suggests any obligation to grant an option.

${ }^{11}$ Shany, supra note 1 , at 303. 
the state - they acquire specific form through application in a specific state. This does not imply subordination-though it does suggest what my argument indeed says: that human rights do not speak to changes in sovereign control over territory. They are silent on this question.

It may jar one's cosmopolitan sensibilities to think that human rights - which aim to pierce the fetish-veil of sovereignty - might have little to say about such an important issue as transfer of sovereignty, and I hardly expect this brief reply to sway any minds not convinced by the full paper. One's disposition towards the uncomfortable but important idea that universal human rights often gain meaning in particular social contexts largely determines one's receptivity to this kind of argument. Such arguments cannot be won, only described and motivated. But I will have more to say about that disposition in the final section.

One more thing this question of "option" suggests: because it would deny individuals the means to reconstitute their polity, it is in effect the right of option that would create a hierarchy - but one that places at its apex the citizenry as a totality - which is to say, the state.

\section{Flux And Convergence: \\ Sovereign Democracy Does What Self-Determination Doesn't}

I should now address that distracting misinterpretation I mentioned. Shany assumes I am making a kind of straight-line attack to show that self-determination affords a right of ethnic secession from existing states. I am not, because, just like Shany, I do not think it does. I completely agree that the lex lata-which one could look up in Brownlie $^{12}$ or Higgins ${ }^{13}$ or Cassese ${ }^{14}$ — does not allow ethnic secession.

\footnotetext{
${ }^{12}$ Ian Brownlie, Principles of Public International Law 490 (6th ed. 2003)

${ }^{13}$ Rosalyn Higgins, Postmodern Tribalism and the Right to Secession: Comments, in Peoples and Minorities in International Law 30, 32 (Catherine Broelmann et al., ed., 1993)

${ }^{14}$ Antonio Cassese, Self-Determination of Peoples: A Legal Reappraisal 334 (1995).
} 
Were I writing a different paper, I would cite Shany as a compact and efficient treatment of this fairly obvious truth.

But my argument is built on something entirely differentsomething with which Shany agrees: the broad powers democratic majorities have in sovereign states to alter their borders and reconstitute their citizenship. This is not self-determination: I state clearly that this process, if described as self-determination, is not supported by international law. Indeed, if I am right that all his other objections fail, then the only way left for Shany to object to the Plan is precisely to characterize it as an improper act of self-determination.

And this is where, I suspect, the most profound disagreement Shany and I have arises - the thing motivating his peculiar misreading: that a democratic majority altering Israel's borders would look curiously like the outcome if one applied classical self-determination; that this functional convergence is not an accident; and that we might need to take this seriously.

Whenever two distinct doctrinal approaches - one compatible with existing norms, the other contravening them-lead to one outcome, we find ourselves at a moment of flux, of opportunity: the doctrines' functional equivalence suggests their fungibility, and thus a moment for re-evaluation. In this case, two doctrines present themselves: a sovereign majoritarian transfer of territory, and an act of self-determination. One is consistent with current norms, the other heterodox, yet they lead to an identical outcome. A candid observer must admit that the logic of self-determination more meaningfully represents the motives of the actors: Sovereign majoritarianism describes a process, but does not supply meaning; it tells us nothing about why a population might choose to organize itself in a certain way, which is precisely what self-determination does tell us.

What I argue, in other words, is that while current self-determination rules bar reconstitution of states, that proscription rests on a doctrinally unstable basis, is inconsistent with our other normative commitments, and vitiates efforts to motivate democratic outcomes; in the harsh circumstances of Cisjordan, it may be bad policy to boot. So I indeed 
conclude that self-determination - the secession of Israel's Jewscould prove normatively defensible (and if it could, it would seem strange to limit self-determination to groups that happen to be electoral majorities in current state borders). But that it is not "supported by positive international law" 15 today: Shany and I agree on that. It is not law-despite this compelling convergence-precisely because of the kind of commitment Shany's argument represents: commitment to a curiously strident cosmopolitanism.

\section{Cosmopolitan Departures}

Shany follows, indeed represents, one of the best and most humane traditions in Israeli thinking, and so what there is of criticism here arises because we speak, not so much of a particular man's view, but of a way of thinking like his. And precisely because it is a humane tradition, it is all the more troubling to observe its descent into formalism, its deformation away from the unmediated embrace of the human and towards something else.

Shany does not deny that groups within the state experience strains, but believes they "should negotiate some inter-communal modus vivendi (or a friendly divorce), or strive to create a new civic identity, which transcends ethnic lines."16 The problem, of course, is all those unhappy marriages where no divorce is possible. In the real world, majorities seldom let minorities leave; why should they, when-precisely because of the democratic process - they hold the dominant position? When the party holding the power, resources and a voting majority feels disinclined to divorce, under the existing doctrinal framework there is no recourse at all. This does not seem like any better a policy for communities than for couples.

But the practical impossibility of divorce is evidently irrelevantwhat matters far more is defense of a polity committed to (at least acquiescent in) the project of co-existence. There is an element of

\footnotetext{
${ }^{15} \mathrm{Id}$. at 10.

${ }^{16} \mathrm{Id}$. at 11 .
} 
formalism, even fantasy, in the policy arguments underpinning this commitment. Consider this key defense of the existing state as the final vessel of national aspiration:

[T]he "locking in" of different groups within a single polity provides the State with relative permanence and stability and conveys to the different ethnic groups within the State the idea that, from an international perspective, they share a single national identity and, perhaps, a common destiny. ${ }^{17}$

Quite apart from one's preferences, does this descriptively, empirically satisfy? Does anyone think that Arabs and Jews actually share a "single national identity"? ${ }^{18}$ If they did, there would be little debate about the "problem" of keeping Israel democratic and Jewish. As for stability - the great contribution of international law's conservatism, Shany tells us-well: I have never heard that word applied to the land west of the Jordan.

The idea of creating a transcendent, civic identity assumes the irrelevance, even undesirability, of ethnic identity, and we should at least admit that this is a difficult claim to make in the face of real human beings who disagree. Leaving this aside, creating a civic identity is problematic enough in a state organized on secular lines, but Israel is an expressly Jewish project, which begs the question of which group has to do the transcending.

From the beginning, the creation of Israel has also been a project of exclusion, actual and definitional. Israel has offered citizenship to all within its borders, but made discretionary choices about who, precisely, is allowed within them. To this day Israel has not fixed its frontiers (as for their part Palestinians have never recognized the

\footnotetext{
${ }^{17} \mathrm{Id}$. at 11 .

${ }^{18}$ The infixation "perhaps" suggests Shany cannot bring himself to say Arabs and Jews have "a common destiny",
} 
borders, or existence, of Israel); Cisjordan is a contested land, not one whose constitutional moment is past.

What is occurring today in Cisjordan is a process of division. The principle of two states - and their inevitability-has been conceded; we are only haggling about borders. A place of division is unpromising and quixotic ground on which to prove a cosmopolitan claim; I think this is why the attempt turns to abstraction as the only way to sustain its insistence on common identity. Shany defends orthodox self-determination because it "simplifies the difficult task of identifying the "people"" and "circumvents the "minority within a minority' conundrum."' 19 But self-identified communities - and the "conundrums" they create-do not go away just because we declare that their state defines their aspirations.

"Locking in" works - except where it doesn't. Unfortunately, "doesn't" covers a great many places for which our present doctrine has no answer; worse, though it springs from humane and cosmopolitan impulses, it provides inapposite, distracting answers positively harmful to other liberal values. Nowhere do we find consideration-I am not speaking of sympathy - for the fact that not "giving up on co-existence" 20 does not merely call individuals to higher ideals, but requires them to do what they do not wish to do. He speaks of options, but Shany is compelling these communities to stay together. What exactly is the rationale for that? The Arabs may not want to leave, ${ }^{21}$ but Lieberman does - is his only option emigration? ${ }^{22}$

\footnotetext{
${ }^{19}$ Shany, supra note 1 , at 292.

${ }^{20} \mathrm{Id}$. at 299.

${ }^{21}$ What would happen if Israel's Arabs demanded separation (not implausible, given the complexity of Israeli Arab identity)? Doctrinally, there would be no change, but objections about real risk and right of option would collapse, and all that would be left is the core of Shany's argument: dividing a polity is simply a per se harm.

${ }^{22}$ Since Lieberman is a relatively recent immigrant, this might be a pleasingly ironic solution. But of course this does not satisfy nearly so well for the sabra, for whom the contours of coexistence were determined by wars and decisions of stateincluding the Law of Return by which Lieberman finds himself in Israel, a citizen.
} 
We should be clear that "giving up," is, in other terms, simply the reconstitution of political units to accord more closely with their members' desires. Why is this so threatening? The insistence that borders cannot be changed by the minority, the majority, or anyone unless everyone agrees, reveals a kind of atavistic commitment to the state - and this is a curious commitment to find in a cosmopolitan argument. Somehow, a project of civic identity has transmuted into fetishization of the particular civic identities we happen to have. Cosmopolitanism was not supposed to end in the strangulation of political choice; it was certainly not supposed to end in the apotheosis of the state. But this is where Shany, and those who think this way, have arrived: at the conflation of human rights with citizenship; at the absolute defense of borders as inviolate normative commitments; at the insistence that, where there is dissatisfaction with a civic community, the only solution is to lock it in.

And there is something else: It turns out Shany actually accepts the idea of ethnic self-determination, so long as it happens in the past. For Shany, communities enjoy a constitutional moment in which selfdetermination is perfected; such a moment happened at the creation of Israel. This view, which justifies Israel as an act of self-determination, but then forever closes that opportunity - to the Palestinians within the state; to the Palestinians under occupation; ${ }^{23}$ to the Palestinians who missed the moment because they had become refugees; to the Jews themselves - reveals a feature that, one would think, cosmopolitanism would not demonstrate: not simply how harsh, nor how abstract it is, but how selective.

\footnotetext{
${ }^{23}$ Shany says the Plan offends because it "interfere[s] with the external boundaries and the demographic makeup of the State of Israel and the nascent Palestinian politythat is, tampering with the territorial integrity of both states." Shany, supra note 1, at 297. Presumably, this implies Israel's abandonment of all claims in the occupied territories, including East Jerusalem, and evacuation of all settlers. I do not know his actual view.
} 
Perhaps I am wrong about the Lieberman Plan. It is troubling to imagine these scraps of land forced into Palestine against the inhabitants' will - complex as that "will" is - just as it is troubling to imagine peoples forced to live together even though, for complex reasons, they no longer wish to. This hardly would be an interesting case if it were not a hard one; it is entirely possible that, on this or that doctrinal point, Shany is right about the Plan crossing lines, violating rights, failing tests.

But what makes the Plan so intriguing as a case is precisely that it invokes that rare thing: a claim by the majority to divide the state. It is this majoritarian element that allows us to explore the contours of the forbidden logic of self-determination. The reconceptualization of selfdetermination I describe is an attempt to develop a normative response to claims of identity and community, and to the evident strains they can create within a polity.

I think the Lieberman Plan presents a profoundly disturbing case. But my stated point and purpose are to consider the Plan as an instance of a more general phenomenon, and I see no reasoned objection to transfers in general. Indeed, for all he says, Shany all but agrees this kind of thing can happen, and does. He does not like it - more than his specific objections, his sensibility makes this clear-but why exactly? Clearly he is concerned to protect human rights - and this out of the most liberal instincts - but his response is to identify the rights of individuals in a way that places a nearly absolute priority on the state itself. We may argue about a particular case - we might even agreebut where defense of rights becomes, in effect, defense of the state, we must ask ourselves: Is there a right to maintain a political union against the wishes of those who share it? Do we wish to defend that? 